DOI: https://doi.org/10.24867/10DS07Vukosavljevic

\title{
STANJE I KARAKTERISTIKE RAZVIJENOSTI DRUMSKOG SAOBRAĆAJA U NAŠOJ ZEMLJI
}

\section{STATE AND CHARACTERISTICS OF ROAD TRAFFIC DEVELOPMENT IN OUR COUNTRY}

\author{
Nina Vukosavljević, Fakultet tehničkih nauka, Novi Sad \\ Oblast - SAOBRAĆAJNO INŽENJERSTVO \\ Kratak sadržaj - Predmet istraživanja ovog rada jeste \section{SAOBRAĆAJA} \\ 2. PODELA I OSNOVNE FUNKCIJE DRUMSKOG
} analiza i značaj drumskog saobraćaja, njegovog stanja $i$ karakteristika u Srbiji.

Ključne reči: Drumski saobraćaj, putna mreža, saobraćajni koridori, razvojni projekti

Abstract - The subject of research in this paper is the analysis and importance of road traffic, its condition characteristics in Serbia.

Keywords: Road traffic, road network, traffic corridors, development projects

\section{UVOD}

Pod saobraćajem se podrazumevaju sveukupni odnosi međuljudskih komunikacija, zatim prenos informacija i podataka, kao i prevoz ljudi i materijalnih dobara.

Uporedo $\mathrm{s}$ razvojem društva, razvijala se nauka o saobraćaju, saobraćajnim komunikacijama i saobraćajnim sredstvima, koja je podsticala i usmeravala razvoj saobraćaja. Danas se može govoriti o pet izgrađenih vidova saobraćaja: železnički, drumski, vodni, vazdušni i telekomunikacioni.

\subsection{Pojam i značenje drumskog saobraćaja}

Drumski saobraćaj je saobraćaj koji se odvija na drumovima. On ima svoja pravila i uređen je zakonima koji su, po kategorijama primenljivi na različite učesnike u saobraćaju, kao i velikim brojem opštih pravila koja važe za sve i stvar su unutar državnih i međunarodnih konvencija, kao i etike učesnika u saobraćaju.

Drumski saobraćaj, ne čine samo pravila. Čine ga i infrastruktura (sa svim putevima, petljama, mostovima i tunelima) na kojoj se pravila primenjuju, i vozila zbog kojih je sve to i osmišljeno.

\subsubsection{Istorijski razvoj drumskog saobraćaja}

Čitav istorijski period razvoja saobraćaja moguće je pratiti od preindustrijskog do savremenih saobraćajnih mreža na početku XXI veka, a kroz pet velikih faza, gde se svaka odlikuje specifičnim inovacijama u transportnom sektoru.

\footnotetext{
NAPOMENA:

Ovaj rad proistekao je iz master rada čiji mentor je bila Milica Miličić, vanr.prof.
}

Podela saobraćaja se može vršiti na razne načine. Kao kriterijumi za podelu mogu nam služiti izvesne tehničke karakteristike, zatim način organizacije prevoza, kao i izvesne ekonomske funkscije pojedinih saobraćajnih delatnosti. Prema načinu prevoza i prevoznih sredstava saobraćajnim putevima, moguće je razlikovati: kopneni, vodni, vazdušni, poštanski i telekomunikacijski saobraćaj. Prema karakteristikama puta, saobraćaj se deli na: drumski, železnički, pomorski, rečmi jezerski, cevovodni, vazdušni, poštanski i telekomunikacijski. Svaka saobraćajna grana ima svoje specifičnosti i tehničko-tehnološke i ekonomske karakteristike koje zavise od prirodnih uslova u kojima se saobraćaj vrši, saobraćajnog puta, vrsti i kvalitetu prevoznog sredstva, transportnog procesa i unutrašnje organizacije svake pojedine grane.

\section{PREDNOSTI I NEDOSTACI DRUMSKOG SAOBRAĆAJA}

Drumski saobraćaj glavnu konkurentsku prednost zasniva na visokoj elastičnosti prevoza. Ta elastičnost počiva na velikoj gustini saobraćajne mreže i relativno malim eksploatacionim jedinicama. Ovaj vid transporta može da obezbedi prevoz raznolikih količina roba na veliki broj odredišta. Bitne prednosti drumskog saobraćaja su relativno mala ulaganja u nabavku prevoznih kapaciteta, koja su dostupna i malim firmama, tako da veliki broj firmi može da poseduje svoj vozni park. Nedostaci drumskog saobraćaja su niska bezbednost, velika energetska potrošnja po jedinici prevoza i visoki eksterniekološki troškovi, zbog zagađivanja životne sredine. Osim toga, nedostatak je i mala transportna sposobnost njegovih transportnih jedinica, što se dobrim delom može otkloniti povećanjem njihovog broja.

\section{ORGANIZACIJA DRUMSKOG SAOBRAĆAJA}

Pod organizacijom se podrazumeva sistem pravila koja koordiniraju sredstva u svrhu ostvarenja određenog rezultata. Organizacija ima svoju strategiju i taktiku koja funkcioniše na osnovu određenih principa, što omogućava racionalno poslovanje privrednih i drugih organizacija. Organizacija znači samo delatnost usklađivanja i usmeravanja sredstava za ostvarenje cilja. Za saobraćajnu delatnost, pa prema tome i delatnost drumskog saobraćaja karakteristična je organizacija u dinamici. Organizacija drumskog saobraćaja se može podeliti na dva područja: 
1. Organizacija preduzeća

2. Poslovna i razvojna organizacija

U osnovne faktore organizacije drumskog saobraćaja spadaju: materijalni faktori i ljudski resursi.

\subsection{Savremeni oblici organizacione strukture drumskog saobraćaja}

Savremeni oblici organizacije zasnivaju se na postavkama teorije sistema, pri čemu se polazi od:

1. Ostvarenja cilja

2. Prilagođavanja sistema u odnos na okolinu

3. Integracije svih delova sistema

Savremena organizacija ne predstavlja zaokruženu celinu i da se uvek može unapređivati promenama koje uslovljavaju tržište, pojava novih informativnih tehnologija, odnosno prema sredini uspostavljanja stanje dinamičke ravnoteže. Može se reći da funkcionalna organizacija predstavlja najjednostavniji i najviši primenjeni model organizacione strukture i zasniva se na funkcionalnom grupisanju poslova, odnosno jedinica. Funkcionalna podela je grupisanje aktivnosti prema funkcijama preduzeća. Prednost funkcionalne podele je što je ta metoda logična $i$ potvrđena drugom primenom. Druga prednost je što sledi načela specijalizacije po zanimanjima i time pridonosi efikasnosti u korišćenju ljudi.

\subsection{Organizaciona struktura drumskog transporta}

Osnovna delatnost drumskog transporta je prevoz putnika i robe koji obavljaju autotransportna preduzeća koja su registrovana za vršenje saobraćaja kao osnovna delatnost. Pored ovih preduzeća kod nas i u svetu postoje preduzeća koja obavljaju transportnu delatnost za sopstvene potrebe kao sporednu delatnost. Ovakvu delatnost mogu obavljati i pojednci za lične potrebe.

\section{STANJE I KARAKTERISTIKE RAZVIJENOSTI DRUMSKOG SAOBRAĆAJA U SRBIJI}

Saobraćajna infrastruktura $\mathrm{i}$ razvijenost saobraćaja $u$ Srbiji, posmatrani po svim važećim parametrima, više su nego loši. Takvo stanje je posledica nedovoljno efikasnih Vlada u proteklim vremenima. Puno zaostajemo, ne samo za EU, već i za zemljama u okruženju.

Tabela1- Prevoz putnika i robe preduzeća iz oblasti saobraćaja u Srbiji

\begin{tabular}{|c|c|c|c|c|}
\hline Godina & $\begin{array}{c}\text { Prevežni } \\
\text { putnici u } \\
\text { hiljadama }\end{array}$ & $\begin{array}{c}\text { Putnički } \\
\text { kilometri u } \\
\text { milionima }\end{array}$ & $\begin{array}{c}\text { Prevežna } \\
\text { roba u } \\
\text { hiljolama } \\
\text { tona }\end{array}$ & $\begin{array}{c}\text { Tonski } \\
\text { kilometri u } \\
\text { milionima }\end{array}$ \\
\hline 2008. & 95328 & 6782 & 22354 & 4789 \\
\hline 2009. & 90423 & 5721 & 22723 & 5092 \\
\hline 2010. & 90232 & 5212 & 25900 & 5421 \\
\hline 2011. & 90221 & 6132 & 27903 & 6902 \\
\hline 2012. & 91882 & 7523 & 29323 & 6998 \\
\hline 2013. & 85232 & 6623 & 28321 & 8400 \\
\hline 2014. & 89232 & 7023 & 31892 & 8013 \\
\hline 2015. & 87447 & 7113 & 23432 & 6013 \\
\hline
\end{tabular}

Drumski saobraćaj u svim segmentima zaostaje za okruženjem zbog lošeg stanja postojeće putne mreže i usporene gradnje saobraćajnih koridora, zatim zbog zaostajanja $u$ primeni savremenih tehnologija $u$ upravljanju saobraćajem i velikim zastareslostima voznog parka.

\subsection{Drumska infrastruktura}

Putnu mrežu Srbije čine saobraćajnice u dužini od oko $40.845 \mathrm{~km}$. Od toga je $835 \mathrm{~km}$ Koridor X, sa kracima Xb i Xc, od čega je završeno svega $57 \%$ trase. Prema kategorizaciji puteva imamo sledeće podatke: putevi prvog reda $4.891 \mathrm{~km}$, autoputevi $634 \mathrm{~km}$, putevi drugog reda $11.540 \mathrm{~km}$ i opštinski putevi $23.780 \mathrm{~km}$. Prema broju stanovnika, dužina saobraćajnica u Srbiji je 2,5 puta manja u odnosu na zemlje u EU. Putna mreža Srbije je jedna od najvećih investicija Srbije i procenjena je na 17 milijardi USD.

\subsection{Drumski teretni saobraćaj}

Drumski transport u Srbiji predstavlja dinamičan i dominantan vid saobraćaja koji učestvuje u prevozu robe sa $52 \%$ (mereno po ostvarenim $\mathrm{t} / \mathrm{km}$ ), a broj teretnih vozila od 2000.godine povećao se za $31 \%$ i broji oko 126.45 vozila. Ovakvo povećanje predstavlja veliko opterećenje za našu ionako lošu infrastrukturu. Starost voznog parka iznosi nešto više od 15 godina.

\subsection{Drumski teretni saobraćaj}

Drumski putnički saobraćaj u Srbiji stagnira. Broj autobusa je manji za $17 \%$ u odnosu na 1996. godinu. Starost voznog parka je slična kao i u teretnom saobraćaju što se negativno odražava na sigurnost u saobraćaju, ubrzano je habanje autobusa zbog loše infrastrukture, otežane su mogućnosti nabavke novog voznog parka i sl.

\subsection{Stanje, problemi, ograničenja}

Zbog dugogodišnjeg nedovoljnog ulaganja u održavanje $u$ rekonstrukciju puteva, stanje putne mreže nije zadovoljavajuće. Oko $32 \%$ državnih puteva staro je preko 20 godina, a svega $14 \%$ do 10 godina. Oko $40 \%$ celokupne mreže ima kolovoz od tucanika ili zemlje. Ovakvo stanje putne mreže uticalo je na smanjenu bezbednost saobraćaja, nizak nivo usluga i visoke troškove eksploatacije i transporta.

\subsection{Održavanje putne mreže}

Kretanje ljudi i roba širom sveta prevashodno zavisi od mreže puteva, shodno tome neophodno je njihovo održavanje. Aktivnosti održavanja mogu da se klasifikuju prema operativnoj frekvenciji na:

\section{- Redovno održavanje \\ - Periodično održavaje \\ - Interventno održavanje}

\subsection{Ciljevi razvoja drumskog saobraćaja}

Osnovni ciljevi razvoja drumskog saobraćaja su: zadovoljavanje prevoznih potreba privrede i stanovništva; povećanje fizičkog obima prevoza robe i putnika, posebno na Koridoru $X$ i tranzitu; povećanje efikasnosti, konkurentnosti, profitabilnosti i kvaliteta usluga; integrisanje $\mathrm{u}$ evropsku putnu mežu; podizanje nivoa bezbednosti saobraćaja na putevima; unapređenje zaštite životne sredine; usklađivanje propisa kojima je uređena oblast drumskog saobraćaja sa propisima EU. 


\subsection{Mere i aktivnosti}

Infrastruktura ima ekomomski i društveni značaj, i predstavlja podsticajni faktor za ubrzan razvoj privrede, regiona $i$ društva. Većim investiranjem smanjiće se zaostajanje Srbije u razvoju infrastrukture za zemljama EU, povećati nivo bezbednosti, smanjiti ljudski i materijalni gubici. Na taj način će se povećati tražnja za prevozom, privući tranzitni saobraćaj, povećati konkurentnost Srbije, što će dati impuls privrednom razvoju, naročito manje razvijenih područja. Prioritet u izgradnji infrastrukture je završetak Koridora X koji ima ekonomski, razvojni i strateški značaj.

\subsection{Saobraćajni koridori Srbije}

Saobraćajni koridori predstavljaju jedan od ključnih aspekata infrastrukture svake nacionalne privrede, regiona, grada i opštine. Generalno je prihvaćen stav da je saobraćajna, pored energetske infrastrukture, najvažniji opšti uslov razvoja države. Pored ključnog uticaja na razvoj privrede, na privlačenje novih stranih investicija, na bolje životne uslove građana, dostignuti nivo razvoja saobraćajnih koridora često predstavlja i pitanje integracija u regionalnu i svetsku privredu. Ovo se posebno odnosi na Srbiju, kao zemlju koja se nalazu „nasred puta“ i nikako se ne može posmatrati izolovano u geopolitičkom smislu.

\subsubsection{Geopolitika koridora}

$\mathrm{Na}$ tri evropske saobraćajne konferencije održane na nivou ministara saobraćaja, doneta je odluka da se izradi evropska mreža koridora. Krajnji cilj formiranja panevropske saobraćajne mreže jeste funkcionalna prekogranična integracija, sa pojednostavljenim i ubrzanim saobraćajnim tokovima, koji podrazumevaju otvorene granice, ali i unapređene i usklađene infrastrukture i usluge, čime se omogućuje slobodno kretanje ljudi, robe, kapitala i informacija.

Panevropski koridor u najvećoj se meri odnosi na zemlje centralne, istočne i južne Evrope i čini osnovu unutrašnje regionalne mreže. Takozvani Koridor 11 (trebalo bi da spoji Rumuniju, Srbiju, Crnu Goru i Italiju trasom TemišvarBeograd-Bar-Bari) još nije zvaničan evropski koridor, što znači da ne spada u prioritetne puteve u pogledu investicija EU.

\subsubsection{Trenutno stanje}

Jedan od bitnih pokazatelja kvantiteta razvoja nekog segmenta saobraćajne mreže jeste njena gustina, kao odnos površine određene zemlje i kilometara izgrađeme saobraćajne mreže.

\section{Grafikon 1. Gustina mreže autoputeva}

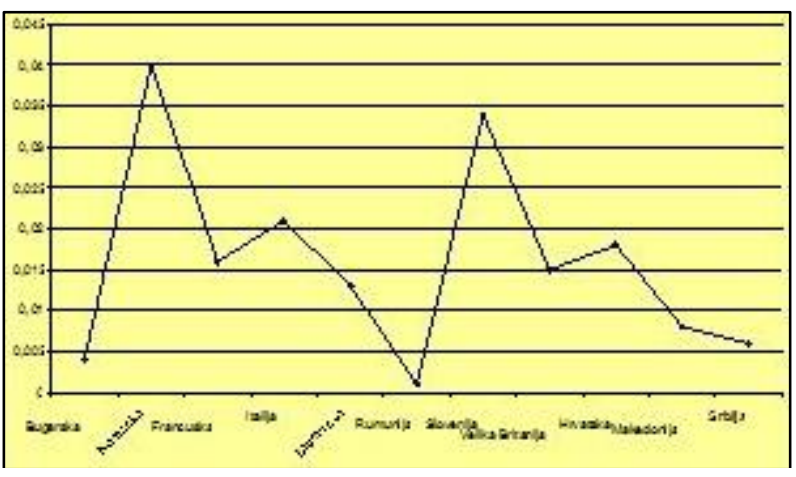

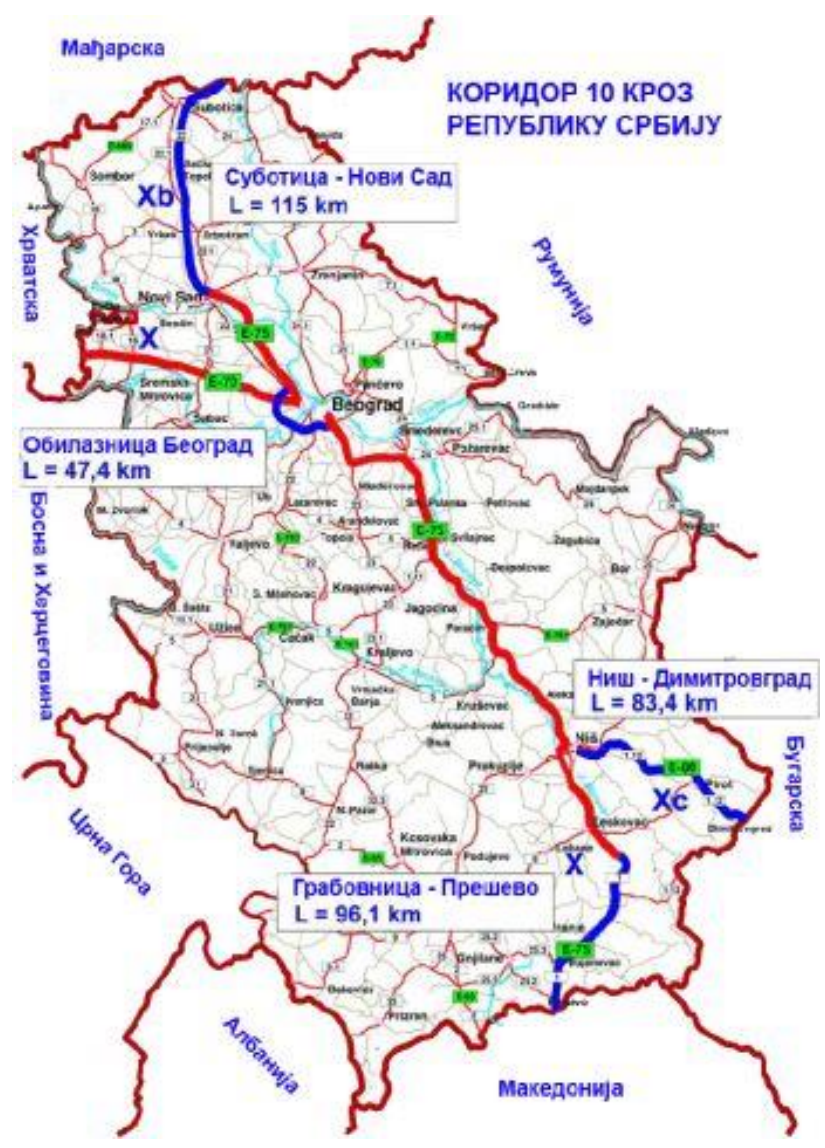

Slika 1. Koridori Srbije

Grafikon 2. Gustina mreže nacionalnih i regionalnih puteva

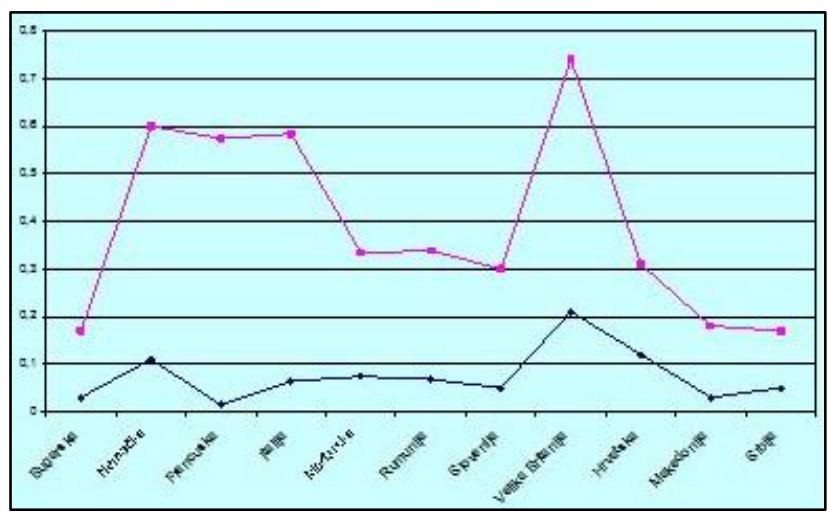

\subsubsection{Interna i eksterna ograničenja}

Nerazvijenost i zapuštenost putne mreže u Srbiji delimično je posledica izolacije i sankcija koje su u Srbiji devedesetih godina nametnule Evropska zajednica i SAD, ali u velikoj su meri, takođe, posledica internih propusta $i$ neozbiljnosti u pristupu ovom pitanju koje u kontinuitetu demonstriraju srpske vlasti, a naročito $u$ protekloj deceniji, nakon otvaranja zemlje ka EU i SAD. Prioriteti u realizaciji projekata menjaju se u zavisnosti od toga koja stranka dominira vladom i resornim ministarstvima. Tenderi za izvođače radova kreiraju se i ugovaraju prema pravilima koja definiše kreditor (npr.vodič za nabavke Evropske investicione banke), a među kriterijumima su odnosi između vrednosti projekta i godišnjeg prometa kompanije, prethodno iskustvo kompanije na sličnim projektima itd. 


\subsection{Ograničenja u pogledu finansiranja projekata}

U poledu finansiranja izgradnje saobraćajnica veliko interno ograničenje predstavlja visina javnog duga naime, javni dug Srbije po podacima nBS iznosi oko $56 \%$ BDP (bruto društveni proizvod).

\subsection{Koridor 10}

Cilj je da se obezbedi održivi ekonomski razvoj i da se državi omogući da iskoristi svoj geografski položaj kako bi nastavila svoj razvoj kao ključna tranzitna država u Trans - Evropskoj transportnoj mreži. Vlada RS zatražila je pomoć Svetske banke u izradi i finansiranju programa za razvoj dveju južnih deonica Koridora X.

\subsection{Razvojni projekti}

\subsubsection{Projekti minimalnih ulaganja}

Uzevši u obzir da su neke deonice putne mreže Srbije u izgradnji ili u fazi pripreme građevinskih radova, sa obezbeđenim sredstvima, a očigledno je da će se ove deonice izgraditi u određenom vremenskom periodu, Konsultant je uključio ove projekte zajedno sa aktivnostima na održavanju puteva u scenariju Minimalno ulaganje. Projekti minimalnog ulaganja će uključiti projekte za svaku vrstu saobraćaja koji su:

- u izgradnji

- u fazi prikupljanja podataka

- našli izvor finansiranja koji je odobren

\subsubsection{Razvojni projekti puteva}

Ovo poglavlje prikazuje razvojne projekte na putnoj mreži u različitoj fazi implementacije i definicije. Ovi projekti su identifikovani od strane Korisnika, a takođe i Konsultanta.

Lista prikazanih projekata nije konačna. Biće dodati drugi projekti u skladu sa nalazima saobraćajnog modela. Lista projekata:

E-75 Horgoš - Novi Sad (projekat RDA1)

Kelebija - E-75 (projekat RDA2)

Grabovnica - BRM (projekat RDA3)

Niš - Dimitrovgrad (projekat RDA4)

Kragujevac - Batočina (projekat RDA5)

Beograd - Požega (projekat RDB6)

\section{ZAKLJUČAK}

Saobraćaj je smišljeno i organizovano kretanje transportnih jedinica na mreži saobraćajnica sa ciljem prevoza ljudi, robe i prenosa informacija od jedne do druge tačke. Prema Zakonu o javnim putevima, put je izgrađena, odnosno utvrđena površina koju kao saobraćajnu površinu mogu da koriste svi ili određeni učesnici u saobraćaju, pod uslovima određenim zakonom i drugim propisima. Relativna dužina puteva u Srbiji je između odgovarajućih vrednosti Austrije i Velike Britanije. Na teritoriji Republike Srbije postoji oko $792 \mathrm{~km}$ puteva Koridora X i njegovih grana X-b i X-c.3.

\section{LITERATURA}

[1] Vračarević, R (2002), Osnove planiranja saobraćaja, Beograd: Fakultet tehničkih nauka.

[2] Žegarac, Z. (1998), Infrastruktura. Beograd: Geografski fakultet.

[3] Basarić, V., Simeunović, M. (2007), Planiranje saobraćaja, Beograd: Fakultet tehničkih nauka.

[4] Vojvodić, S. (2009), Ekonomika saobraćaja, Fakultet za menadžment u saobraćaju i komunikacijama, Berane.

[5] Božić, V. (2009), Ekonomija saobraćaja, Centar za izdavačku delatnost Ekonomskog fakulteta, Beograd.

[6] Perišić, R.A. (2002), Savremene strategije $i$ tehnologije razvoja transporta-koridori X $i$ VII, logistika i informatika, Srpska akademnija nauka i umetnosti, Beograd.

[7] Banković, R. (1994), Organizacija i tehnologija javnog gradskog putičkog prevoza, Saobraćajni fakultet, Beograd.

\section{Kratka biografija:}

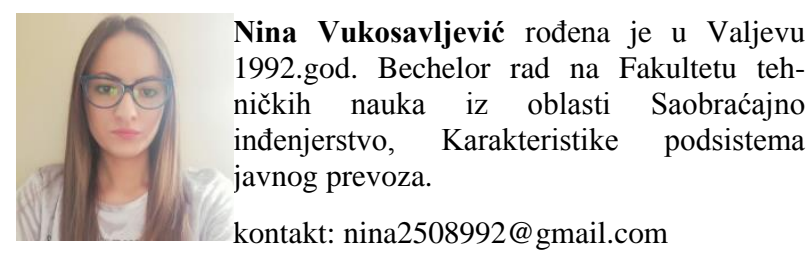

